\title{
Satisfaction Level of Migrant Agriculture Labour in Rangareddy District Of Andhra Pradesh - An Economic Analysis
}

\author{
S.Narasimham ${ }^{1}$, Dr.N. Vasudev ${ }^{2}$ \\ 1(Department of Agriculture Economics/Acharya N.G.R.Agriculture University,India) \\ 2(Department of Agriculture Economics/Acharya N.G.R.Agriculture University,India)
}

\begin{abstract}
The Mobility for employment is an important human right. Migration has become a key facet of today's world. In recent years, Rangareddy district of Andhra Pradesh is witnessing large inflow of migrant workers from different parts of the country. Labours from different states like Kerala, Bihar, Orissa, and Karnataka Migrate to Andhra Pradesh especially Rangareddy district for improving their family economy where local economy offer limited livelihood alternatives. Rangareddy district provide employment opportunity for those people in different sectors. With the rapid growth of states economy and increased infrastructure and construction sectors provides many opportunities for employment. It is also expected that in coming years it will grow faster. This study is an overall effort to measure the relationship between socio economic factors and the level of satisfaction among migrated agriculture labour in Rangareddy district and is mainly aimed to know the various economic and demographic attributes of the migrated labourers.
\end{abstract}

Key words: Migration, Labourers, employment, Opportunities.

\section{Introduction}

Migration is normally treated as an economic phenomenon though non economic factors also have some influence. Labour migration is generally defined as a cross-border movement for the purposes of employment and better living in a foreign country (Acharya et al., 1991)[1]. However, there are no universally accepted definitions of labour migration. The term "labour migrant" can be used restrictively to only cover the movement for the purpose of employment. Millions of people move from their home countries for work. Migrants look for any work as they are in poverty and insecurity (Castles, S. 2000)[2]. Migrant agriculture labours make significant impact on the economy. They face many challenges like mistreatment and discrimination. Both skilled and unskilled migrant agriculture labour are required to complete many work.

\section{Need Of The Study}

The study of agriculture labour migration is of great significance for the development and reconstruction of rural areas in Andhra Pradesh. People movement from rural areas to urban areas since the living condition is better in urban areas (De Haan et al., 2002)[3]. In rural areas, they face many problems like poverty, high population pressure, lack of health care facilities, education, etc. In addition, people migrate due to wars, local conflicts and natural disasters such as cyclonic storms, flood, earthquake, Tsunami, drought. The overseas Indian population spans across the globe and almost present in all the continents. In this study the economic conditions of migrated agriculture labour and their level of study has been analysed.

\section{Statement Of The Problem}

Unemployment is main reason of migration for job opportunity in many places. The choice of destination is greatly constrained by expenses- travel costs, official permit fee and all too often, the unofficial levies of intermediary fixers. The poorest are the least able to overcome these obstacles and economic migrants head for the nearest state or district. In many states of India, migrated labours has become a package commodity. Established channels of migration are insufficient to absorb the supply of labour. Many migrant labourers are illiterate and belong to the poorest sections of the society. Most of the migrated labours in Rangareddy District do not have a permanent job and keep shifting from one area to another and also they lack bargaining in getting wages, forced to accept unhealthy working situation.

\section{Research Methodology}

For the present study, Rangareddy district was purposively selected due to lack of unemployment, problems of various unorganized sectors and changing pattern in migrated workers life style. From Rangareddy district, 200 migrated labours were selected by using stratified sampling method. The research result is mainly based on the systematic method of data collection and analysis. Both the primary and secondary data is used for 
the current study. The primary data was collected from the migrated workers who were all working in various sectors of Rangareddy district. The information was gathered through personal interview method. From the selected migrant labours, data regarding present situation, employment opportunities, income, problems and their satisfaction levels were collected. Based on the data obtained from survey, as well as data from secondary sources collected and presented in the study, descriptive and analytical research were conducted which is considered most appropriate for the study.

\section{Objectives Of The Study}

1. To analyse the satisfaction levels of migrated agriculture labours in Rangareddy District.

2. To find out the socio economic background of the migrated labours in Rangareddy district.

\section{Review Of Literature}

Mabogunje (1981)[4] believes that government intervention is necessary to regulate migration and to mitigate its adverse consequences. He suggested five arguments namely, economic, environmental, social, administrative and political for information resources. Bryceson (2003)[5] in his study "Sub-Saharan Africa Betwixt and Between: Rural Livelihood Practices and Policies" found that mobility patterns are highly differentiated according to levels of income, size and type of settlement in which they reside. Kundu (2003)[6] in his study "Urbanization and urban governance: search for a perspective beyond neo-liberalism" concluded that the internal migration opportunities and employment are support migrants while looking for work thus lowering the costs and risks of internal migration.

\subsection{MULTIPLE REGRESSION ANALYSIS}

\section{Data Analysis And Interpretation} independent

The following analysis shows the relationship between level of satisfaction in migration and seven variables that were studied.

$\mathrm{T}$

ABLE 1: MULTIPLE REGRESSION ANALYSIS

\begin{tabular}{|l|l|l|l|l|l|}
\hline S.No & Variables & B & Std. Error & T & P \\
\hline 1 & (Constant) & 37.634 & 6.883 & 5.467 & .000 \\
\hline 2 & Gender & -.479 & .446 & -1.074 & .284 \\
\hline 3 & Age & 10.405 & 5.586 & 1.863 & .064 \\
\hline 4 & Marital Status & .221 & 1.123 & .196 & .844 \\
\hline 5 & $\begin{array}{l}\text { Education } \\
\text { Qualifications }\end{array}$ & -2.457 & 1.245 & -1.974 & .050 \\
\hline 6 & Experience & -3.174 & .887 & -3.578 & .000 \\
\hline 7 & Annual Income & -.366 & .881 & -.416 & .678 \\
\hline 8 & Family Size & 1.880 & .751 & 2.504 & .013 \\
\hline
\end{tabular}

\begin{tabular}{|l|l|l|l|l|}
\hline Model & R & R Square & Adjusted R Square & Std. Error of the Estimate \\
\hline 1 & .394 & .155 & .124 & 7.763 \\
\hline
\end{tabular}

ANOVA

\begin{tabular}{|l|l|l|l|l|l|}
\hline & Sum of Squares & Df & Mean Square & F & Sig. \\
\hline Regression & 2123.169 & 7 & 303.310 & & \\
\hline Residual & 11570.586 & 192 & 60.263 & & \\
\hline Total & 13693.755 & 199 & & & \\
\hline
\end{tabular}

It shows the four independent variables contribute on the variation in the level of satisfaction in migration of agriculture labour and statistically significant at $1 \%$ and $5 \%$ level.

\subsection{AGE AND SATISFACTION LEVELS OF MIGRANTS}

TABLE 2: AGE AND SATISFACTION LEVELS OF MIGRANTS

\begin{tabular}{|c|c|c|c|c|c|c|c|}
\hline \multirow[t]{2}{*}{ S. No } & \multirow[t]{2}{*}{ Age } & \multirow{2}{*}{$\begin{array}{l}\text { No. Of } \\
\text { migrants }\end{array}$} & \multirow[t]{2}{*}{$\%$} & \multirow[t]{2}{*}{ Average } & \multicolumn{2}{|c|}{ Range } & \multirow[t]{2}{*}{ S.D } \\
\hline & & & & & Min & Max & \\
\hline 1 & Below 25 & 146 & $73.0 \%$ & 57.34 & 23 & 78 & 16.614 \\
\hline 2 & $25-35$ & 40 & $20.0 \%$ & 52.18 & 22 & 78 & 18.119 \\
\hline \multirow[t]{2}{*}{3} & Above 35 & 14 & $7.0 \%$ & 53.69 & 32 & 78 & 20.064 \\
\hline & Total & 200 & $100 \%$ & & & & \\
\hline
\end{tabular}


It is observed from the above table that the level of satisfaction occurred by the migrated agriculture labours in various sectors among the below 25 age group migrants ranged between 23 and 78 with an average of 57.34 The level of satisfaction occurred by the migrated labourers in various sectors among the 25 to 35 age category of migrants ranged between 22 and 78 with an average of 52.18. On the other hand, the level of satisfaction occurred by the migrated labourers in various sectors among the above 35 age group migrants ranged between 32 and 78 with an average of 53.69. From the analysis it is concluded that below 25 age group agriculture labour migrants generating the maximum level of satisfaction in various sectors (Chant, S. 1992)[7]

\subsection{Gender And Satisfaction Levels Of Migrants}

TABLE 3: GENDER AND SATISFACTION LEVELS OF MIGRANTS

\begin{tabular}{|c|c|c|c|c|c|c|c|}
\hline \multirow[t]{2}{*}{ S. No } & \multirow[t]{2}{*}{ Gender } & \multirow{2}{*}{$\begin{array}{l}\text { No. of } \\
\text { migrants }\end{array}$} & \multirow[t]{2}{*}{$\%$} & \multirow[t]{2}{*}{ Average } & \multicolumn{2}{|c|}{ Range } & \multirow[t]{2}{*}{ S.D. } \\
\hline & & & & & Min & Max & \\
\hline 1 & Female & 53 & $26.5 \%$ & 49.60 & 23 & 78 & 15.680 \\
\hline 2 & Male & 147 & $73.5 \%$ & 58.41 & 22 & 78 & 17.168 \\
\hline & Total & 200 & $100.0 \%$ & & & & \\
\hline
\end{tabular}

It could be analysed from the above table that the level of satisfaction occurred by the migrated labourers in various sectors among the female migrants ranged between 23 and 78 with an average of 49.60 . Whereas male migrants level of satisfaction occurred by the migrated agriculture labour in various sectors ranged between 22 and 78 with an average of 58.41. Thus the table reveals that the maximum level of satisfaction occurred by the migrated labourers in various sectors was the male labourers in the study area.

7.4 Educaitonal Qualificaiton And Satisfaction Levels Of Migrants TABLE 4: EDUCAITONAL QUALIFICAITON AND SATISFACTION LEVELS OF MIGRANTS

\begin{tabular}{|l|l|l|l|l|l|c|c|}
\hline $\begin{array}{l}\text { S. } \\
\text { No }\end{array}$ & $\begin{array}{l}\text { Educational } \\
\text { qualification }\end{array}$ & $\begin{array}{l}\text { No. of } \\
\text { migrants }\end{array}$ & \% & Average & Range & S.D \\
\hline 1 & Illiterate & 77 & $38.5 \%$ & 52.67 & 32 & 78 & 16.737 \\
\hline 2 & 10 th & 49 & $24.5 \%$ & 56.29 & 22 & 78 & 16.291 \\
\hline 3 & 12 th & 39 & $19.5 \%$ & 59.32 & 23 & 78 & 18.263 \\
\hline 4 & Graduation & 35 & $17.5 \%$ & 59.69 & 32 & 77 & 17.482 \\
\hline & Total & 200 & $100.0 \%$ & & & & \\
\hline
\end{tabular}

It could be observed from the above table that the level of satisfaction occurred by the migrated agriculture labourers in various sectors among the illiterate level migrants ranged between 32 and 78 with an average of 52.67. The level of satisfaction occurred by the migrated labourers in various sectors among the 10th level migrants ranged between 22 and 78 with an average of 56.29. The level of satisfaction occurred by the migrated labourers among higher secondary level migrants in various sectors ranged between 23 and 78 with an average of 59.32. The Level of satisfaction occurred by the migrated labourers in various sectors among the graduation level migrants ranged between 32 and 77 with an average of 59.69. From the analysis it is noted that the maximum level of satisfaction occurred by the migrated labourers in various sectors was among the migrants of higher secondary level education.

\subsection{Marital Status And Satisfaction Levels Of Migrants}

TABLE 5: MARITAL STATUS AND SATISFACTION LEVELS OF MIGRANTS

\begin{tabular}{|c|c|c|c|c|c|c|c|}
\hline \multirow[t]{2}{*}{ S. No } & \multirow[t]{2}{*}{ Income } & \multirow{2}{*}{$\begin{array}{l}\text { No. of } \\
\text { migrants }\end{array}$} & \multirow[t]{2}{*}{$\%$} & \multirow[t]{2}{*}{ Average } & \multicolumn{2}{|c|}{ Range } & \multirow[t]{2}{*}{ S.D. } \\
\hline & & & & & Min & Max & \\
\hline 1 & below $1,00,000$ & 124 & $62.0 \%$ & 57.11 & 22 & 77 & 17.535 \\
\hline 2 & $1,00,001$-2 lakh & 53 & $26.5 \%$ & 53.39 & 23 & 77 & 16.425 \\
\hline \multirow[t]{2}{*}{3} & above 2 lakh & 23 & $11.5 \%$ & 57.00 & 32 & 78 & 16.497 \\
\hline & Total & 200 & 100.0 & & & & \\
\hline
\end{tabular}

It could be observed from the above table that the level of satisfaction occurred by the migrated labourers in various sectors among the migrants earning below Rs.1,00,000 income ranged between 22 and 77 with an average of 57.11. The level of satisfaction occurred by the migrated labourers in various sectors among the migrants earning Rs. $1,00,001$ to Rs. 2,00,000 income ranged between 23 and 77 with an average of 53.39. The level of satisfaction occurred by the migrated labourers in various sectors among the migrants of above Rs. 2,00,000 income group ranged between 32 and 78 with an average of 57.00. Thus it is concluded from the analysis that the level of satisfaction occurred by the migrated agriculture labourers in various sectors was at the maximum among the above Rs. 2,00,000 income group of the migrants than the other income group of migrants. 


\section{Findings}

1. It is pinpointed that below 25 age group of migrants generating the maximum level of satisfaction in various sectors.

2. It is identified that maximum level of satisfaction occurred by the migrated labourer in various sectors was the male migrants in the study area.

3. It is noted that the maximum level of satisfaction occurred by the migrated labourers in various sectors was among the migrants of higher secondary level education.

4. It is observed that the maximum level of satisfaction occurred by the migrated labourers in various sectors was among the migrants of married category than the unmarried migrants.

5. It is showed that the level of satisfaction occurred by the migrated labourers in various sectors was at the maximum among the above Rs. 2,00,000 income group of the migrants than the other income group of migrants.

\section{Conclusion}

The internal migration has always arisen mainly from the difficulty of finding and adequate livelihood in one's native place, and this is the predominant force which impels the Indian villagers to seek industrial employment. Most of the migrated workers have good opinion about their job and are satisfied with most of the satisfaction factors. But there are certain discrepancies such as feeling some time burden in their job, training, working environment, no opportunity to expose talents and promotional basis is not satisfying the employees. Migrants are working with loyal for long periods because of the reorganisation, responsibility given by the company and healthy relationship between the management and employees and among co workers.

\section{References}

[1] Acharya, Sarthi, and A.V. Jose (1991), "Employment and Mobility: A Study among Workers of Low-Income Households in Bombay City", ILO-ARTEP Working Papers, New Delhi.

[2] Castles, S. (2000), "International Migration at the Beginning of the Twenty First Century: Global Trends and Issues", International Social Science Journal, 8(1), 269-280.

[3] De Haan, A. Brock, K. and Coulibaly, N. (2002), 'Migration, Livelihoods and Institutions: Contrasting Patterns of Migration in Mali', Journal of Development Studies special issue.

[4] Maboganje, (1981), Rural-urban migration: Dimensions, causes, issues and policies, in Prospects for Employment Opportunities in the Nineteen Seventies. Ed. Richard Jolly, Cambridge: Cambridge University Press, pp 41-45.

[5] Bryceson, (2003), Sub-Saharan Africa Betwixt and Between: Rural Livelihood Practices and Policies" Cambridge: Cambridge University Press, pp 68-77.

[6] Kundu (2003) in his study "Urbanization and urban governance: search for a perspective beyond neo- liberalism Working Paper 16, Manchester: Chronic Poverty Research Centre, Institute for Development Policy and Management, University of Manchester.

[7] Chant, S. (1992), Gender and Migration in Developing Countries, London: Belhaven Press. 